\title{
Premonitory sign of heart block in acute posterior myocardial infarction
}

\author{
A. Barrillon, M. Chaignon, L. Guize, and A. Gerbaux \\ From Service de Cardiologie, Hôpital Boucicaut, Paris, France
}

The appearance of the $Q R S$ complex in leads $V_{3} R$ and $V 4 R$ was analysed in a series of 94 patients with acute posterior myocardial infarction. The cases of posterior myocardial infarction with direct signs of injury ( $S T$ segment elevation with a rise of $0.5 \mathrm{~mm}$ or more of point $\mathcal{F}$ and/or $Q S$ pattern) in leads $V 3 R$ and/or $V 4 R$ were complicated three times as often by atrioventricular block as those in which such signs were absent $(66 \%$ and $22 \%$, respectively; $P<0.00 I$ ). When one of these signs was present in leads $V_{3} R$ and $/$ or $V 4 R$, the disorder of conduction was 'severe' (complete atrioventricular block or sinoatrial block with pauses) in half the cases and 'unstable' (bradycardia below 50 beats/min; ventricular pause with or without syncope; widening of QRS complex; ventricular hyperexcitability) in one-third, justifying the introduction of a stimulating catheter. Such disorders were found, respectively, only $I$ in 7 (14\%), and less than $I$ in $10(8 \%)$ when these signs were absent $(P<0.00 I)$. The association of $S T$ segment elevation and $Q S$ pattern was rarer $(15$ cases) than the isolated finding of either sign. It was found in the most severe disorders of atrioventricular conduction. The changes observed in leads $V_{3} R$ and/or $V_{4} R$ before the appearance of atrioventricular block enable one to predict which patients with posterior myocardial infarction are the most likely to develop atrioventricular block. These electrocardiographic features seem to indicate septal involvement.

The disorders of atrioventricular conduction in posterior myocardial infarction are usually well tolerated (Delahaye et al., 197I; Hackel and Estes, 1971; Kaltman, 197I ; Lassers and Julian, 1968); they usually disappear spontaneously within two or three days (Norris, 1969), and do not always require the introduction of a stimulating catheter (Christiansen, Haghfelt, and Amtorp, 1973; Friedberg, Cohen, and Donoso, 1968). However, some cases of posterior myocardial infarction are complicated by unstable atrioventricular block (Guerot et al., 1973), sometimes with ventricular pause or junctional escape rhythm with critical slowing of heart rate to 20 or 30 beats/min (Slama, Motte, and Coumel, 1971), justifying intracavitary pacing through a stimulating catheter (Watson and Goldberg, 197I), which clearly decreases the mortality (Schluger, Iraj, and Edson, 1970). A review of the electrocardiograms, including the right praecordial leads $V_{3} R$ and $V_{4} R$, recorded in 94 cases of acute posterior myocardial infarction, was undertaken in order to identify the patterns preceding the appearance of atrioventricular block (Chaignon, 1972).

Received 16 May 1974.

\section{Patients}

The 94 patients with acute posterior myocardial infarction were admitted to the Intensive Coronary Care Unit of Boucicaut Hospital from May 1969 to October 1972: 8I per cent were men, and the mean age was 60 in men and 68 in women (range: 37 to 83). Almost half the patients were between 60 and 70. The location of the infarction was strictly posterodiaphragmatic (direct signs of necrosis in leads II, III, aVF) in 22 cases; it overlapped the basal area (direct signs of necrosis in leads II, III, aVF, V8, V9) in 26 cases, encroached broadly on the laterobasal area (direct signs of necrosis in leads II, III, aVF, V6, V7, V8, V9) in 30 cases, and lay in the laterobasal area (direct signs of necrosis in leads V6, V7, V8, V9) in 3 cases. Lastly, there was a group of 13 patients with recurrent myocardial infarction. In these patients, the previous infarction had been either posterior or in another location (Table I). In all these cases, the appearance of the QRS complex and the morphology of the ST segments in leads $V_{4} R$ and $V_{3} R$ were analysed. Elevation of the ST segment was defined as a rise of point $\mathrm{J}$ equal to or greater than $0.5 \mathrm{~mm}$. When present, these changes resembled the current of injury found in leads II, III, and aVF. The ST segment elevation found ranged from 0.5 to $\mathrm{I} \mathrm{mm}$ in 40 cases and exceeded $2 \mathrm{~mm}$ in 4 cases. 
TABLE I Location of 94 acute posterior myocardial infarctions and incidence of atrioventricular conduction disorders

\begin{tabular}{lll}
\hline $\begin{array}{l}\text { No. of } \\
\text { cases }\end{array}$ & Location & $\begin{array}{l}\text { Number of cases } \\
\text { with atrioventricular } \\
\text { conduction disorders }\end{array}$ \\
\hline 22 & $\begin{array}{l}\text { Posterodiaphragmatic } \\
\text { Posterodiaphragmatic and } \\
\text { basal }\end{array}$ & 16 \\
30 & $\begin{array}{l}\text { Posterodiaphragmatic and } \\
\text { laterobasal }\end{array}$ & 9 \\
3 & $\begin{array}{l}\text { Laterobasal } \\
\text { Posterior recurrences }\end{array}$ & 9 \\
13 & Total & 60 \\
94 & & $40(42 \cdot 5 \%)$
\end{tabular}

* Location of the 13 recurrent myocardial infarctions: posterodiaphragmatic in 6 cases (location of the previous myocardial infarction: anterior in 3 cases, posterior in I case, lateral in 2 cases); posterodiaphragmatic and basal in 2 cases (location of the previous myocardial infarction: posterior in 2 cases); posterodiaphragmatic and laterobasal in 5 cases (location of the previous myocardial infarction: anterior in 3 cases, posterior in I case, lateral in I case).

Disorders of atrioventricular conduction were observed in 40 cases $(42.5 \%)$. The incidence of conduction disorders is related to the location of myocardial infarction in Table $\mathrm{r}$. Atrioventricular block occurred twice as often in patients with posterodiaphragmatic myocardial infarction ( 16 cases) as in those with posterobasal ( 9 cases) or posterolaterobasal myocardial infarction (9 cases). In the three cases of laterobasal myocardial infarction, atrioventricular conduction remained normal. In the patients with recurrent myocardial infarction, there were 6 cases of atrioventricular block. Among these 40 cases of atrioventricular block, there were 23 cases of third degree block and 6 cases of lesser conduction disorders with syncope (4 cases of first or second degree atrioventricular block and 2 cases of sinoatrial block). Severe conduction disorders were thus found in 72.5 per cent of cases of atrioventricular block (29 out of 40) and in 31 per cent of all cases with acute posterior myocardial infarction (29 out of 94) (Table 2).

\section{Anatomical findings}

Out of these 94 patients with acute posterior myocardial infarction, Io died in the intensive care unit (10.6\%). Necropsy was performed in only 8 cases: 4 of these patients had shown no disorder of atrioventricular con- duction and there were no significant changes in leads $V_{3} R$ and $V_{4} R$; the septal changes found were those found in any posterior myocardial infarction. The other 4 had shown a third degree atrioventricular block, and among these cases, there was a case of recurrent myocardial infarction, whereas it was the first attack in the other 3. In these 3 cases, there was a I to $3 \mathrm{~mm}$ ST segment elevation in leads $V_{3} R$ and $V_{4} R$. In all 3 cases, the septal involvement was extensive, with a rupture of the septum in one case. Histological examination of the area of the atrioventricular node and bundle was performed by Professor Lenègre: the atrioventricular node and main bundle were partially destroyed.

\section{Results}

The morphology of the QRS complex and ST segment in leads $V_{3} R$ and $V_{4} R$ were related to the status of atrioventricular conduction (Table 3 ). Besides the group of 54 patients with normal atrioventricular conduction and the group including all cases of atrioventricular conduction disorders (40 patients), irrespective of their severity, we distinguished two subgroups; the former comprised 29 cases of severe conduction disorders (complete atrioventricular block or sinoatrial block with pauses) and the latter 20 cases of 'unstable' atrioventricular block (bradycardia below 50 beats/min; ventricular pauses with or without syncope; widening of QRS complex; ventricular hyperexcitability) requiring the temporary introduction of a stimulating catheter. In considering QS pattern associated with ST segment elevation, we excluded the I 3 cases of recurrent myocardial infarction, so that the results would not be invalidated by the existence of a previous infarction. When evaluating the incidence of either sign, raised ST segment and/or QS pattern, we excluded the 6 cases of recurrent myocardial infarction with previous anterior necrosis in order that the origin of conduction disorders should be unequivocal.

\section{ST segment elevation}

ST segment elevation, as defined above, was observed in 72 per cent of all cases with atrioventricular conduction disorders $(76 \%$ of cases with severe conduction disorders, $80 \%$ of cases

TABLE 2 Severity of atrioventricular conduction disorders

\begin{tabular}{lll}
\hline $\begin{array}{l}\text { No. of cases with acute posterior } \\
\text { myocardial infarction }\end{array}$ & $\begin{array}{l}\text { No. of cases with atrioventricular } \\
\text { conduction disorders }\end{array}$ & $\begin{array}{l}\text { No. of cases with severe atrioven- } \\
\text { tricular conduction disorders }\end{array}$ \\
\hline 94 & $40(42.5 \%)$ & $29 \star(31 \%)$ \\
\hline
\end{tabular}

* 23 cases of third degree atrioventricular block, 4 cases of first or second degree atrioventricular block with syncope, 2 cases of sinoatrial block with syncope. 

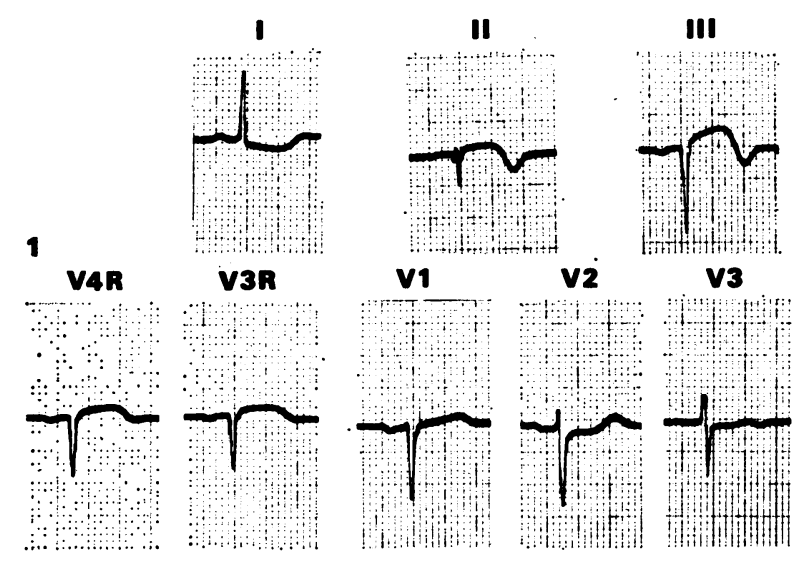

v3
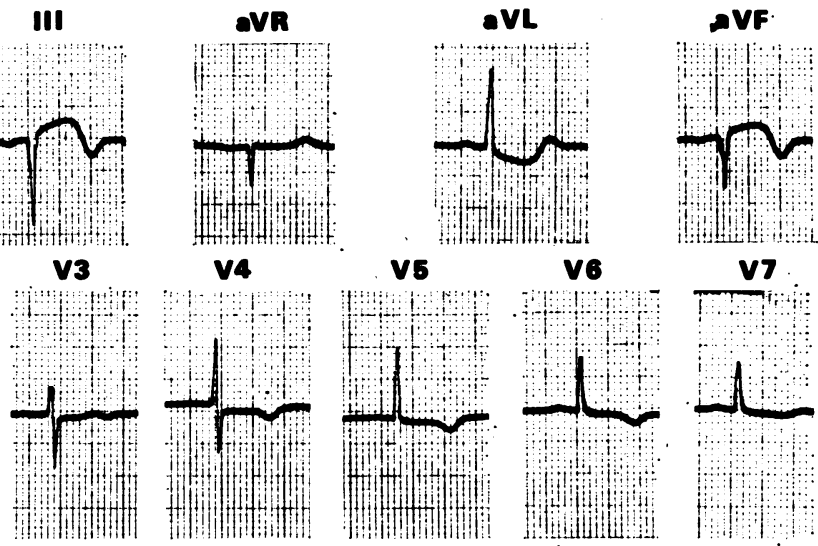

v4
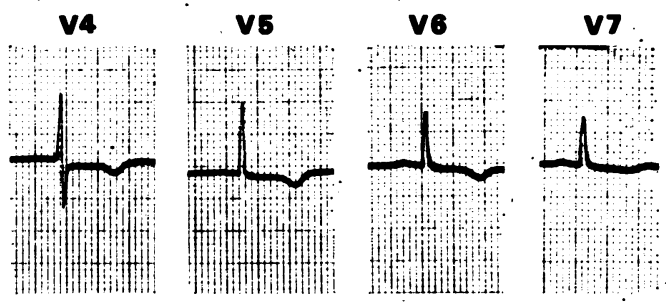

I

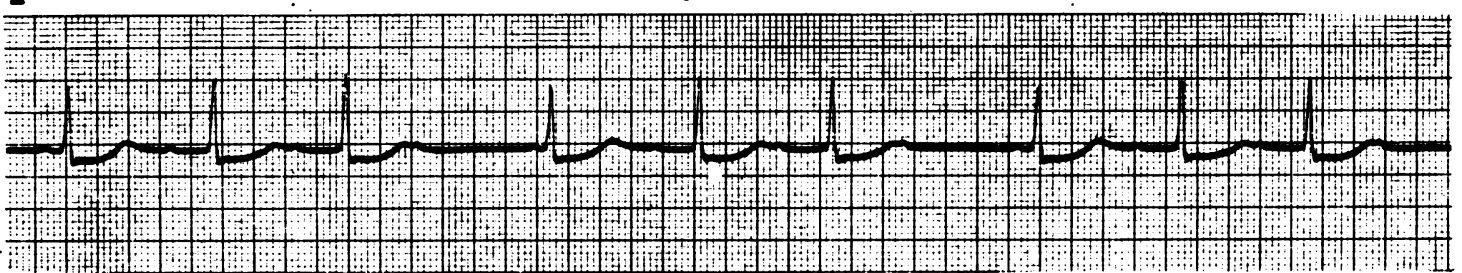

3

$\mathbf{I}$

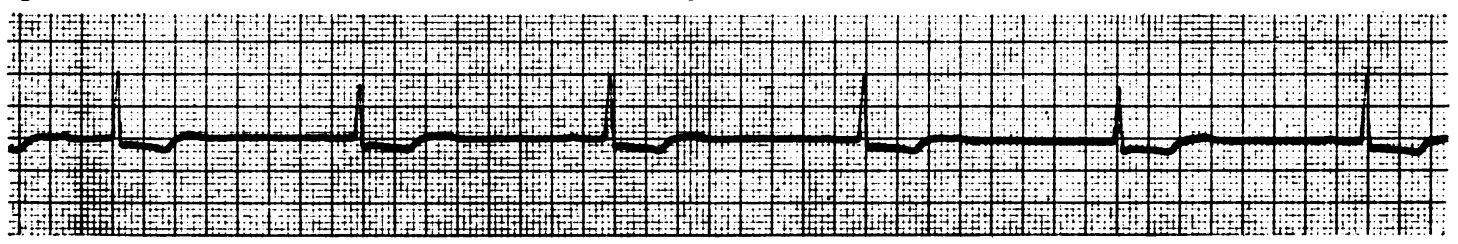

FIG. I Acute posterodiaphragmatic myocardial infarction in a 5I-year-old woman. Stimulation with intracavitary catheter from day 4 to day 7. Return to sinus rhythm on day 7 with normal intracardiac conduction. The successive tracings reproduced show: I) day $I$ (6th hour): presence of $Q S$ pattern and $S T$ segment elevation $(I \cdot 5 \mathrm{~mm})$ in leads $V_{4} R$ and $\left.V_{3} R ; 2\right)$ day 4: second degree atrioventricular block with Wenckebach's periods; 3) day 5 (after discontinuing pacing): 2:I atrioventricular block with bradycardia (37 beats/min).

with unstable atrioventricular block) and in 28 per cent of cases without conduction disorders.

\section{QS pattern}

This pattern occurred less frequently, in 47 per cent of all cases with atrioventricular conduction disorders $(54 \%$ of cases with severe conduction disorders, $53 \%$ of cases with unstable atrioventricular block), and in 15 per cent of cases without conduction disorders.

Both signs (elevated ST segment and QS pattern) were found together in 35 per cent of all cases with atrioventricular conduction disorders $(42 \%$ of cases with severe conduction disorders, $53 \%$ of cases with unstable atrioventricular block) and in 6 per cent of cases without disorders of atrioventricular conduction. Either or both signs (raised ST segment and/or QS pattern) were found in 75 per cent of all cases with atrioventricular conduction disorders $(89 \%$ of cases with severe conduction disorders, $83 \%$ of cases with unstable atrioventricular block) and in 25 per cent of cases without disorders of atrioventricular conduction. The differences found between the control group without disorders of atrioventricular conduction and all 3 groups with disorders of atrioventricular conduction are statistically highly significant $(P<0.001)$. There was no 
TABLE 3 Atrioventricular conduction and appearance of $V_{3} R$ and $V_{4} R$

\begin{tabular}{|c|c|c|c|c|}
\hline $\begin{array}{l}\text { Morphology in } V_{4} R \\
\text { and } V_{3} R\end{array}$ & $\begin{array}{l}\text { Normal atrioventricular } \\
\text { conduction } \\
(54 \text { cases })^{\star}\end{array}$ & $\begin{array}{l}\text { Atrioventricular } \\
\text { conduction disorders } \\
(40 \text { cases })^{\star \star}\end{array}$ & $\begin{array}{l}\text { Severe atrioventricular } \\
\text { conduction disorders } \\
(29 \text { cases })^{\star \star \star}\end{array}$ & $\begin{array}{l}\text { 'Unstable' atrio- } \\
\text { ventricular conduction } \\
\text { disorders } \\
\text { (20 cases) })^{\star \star \star \star}\end{array}$ \\
\hline ST elevation & $\begin{array}{l}28 \% \\
(15)\end{array}$ & $\begin{array}{l}72 \% \\
(29)\end{array}$ & $\begin{array}{l}76 \% \\
(22)\end{array}$ & $\begin{array}{l}80 \% \\
\text { (16) }\end{array}$ \\
\hline QS & $\begin{array}{c}15 \% \\
(7)\end{array}$ & $\begin{array}{l}47 \% \\
\text { (I6) }\end{array}$ & $\begin{array}{l}54 \% \\
\text { (13) }\end{array}$ & $\begin{array}{c}53 \% \\
(9)\end{array}$ \\
\hline ST elevation + QS 1 & $\begin{array}{l}6 \% \\
\text { (3) }\end{array}$ & $\begin{array}{l}35 \% \\
\text { (I2) }\end{array}$ & $\begin{array}{l}42 \% \\
\text { (10) }\end{array}$ & $\begin{array}{c}53 \% \\
(9)\end{array}$ \\
\hline ST elevation and/or QS ${ }^{2}$ & $\begin{array}{l}25 \% \\
\text { (13) }\end{array}$ & $\begin{array}{l}75 \% \\
(28)\end{array}$ & $\begin{array}{l}89 \% \\
(25)\end{array}$ & $\begin{array}{l}83 \% \\
(15)\end{array}$ \\
\hline
\end{tabular}

Actual number of cases is in parentheses.

${ }_{1}^{1}$ Excluding the 13 cases of recurrent myocardial infarction (6 with disorders of atrioventricular conduction and 7 with normal atrioventricular conduction): this decreases the number of cases with normal atrioventricular conduction to $47^{\star}$, the number of cases with atrioventricular conduction disorders to $34^{\star \star}$, the number of cases with severe atrioventricular conduction disorders to $24^{\star \star \star}$, and the number of cases with 'unstable' atrioventricular conduction disorders to $17^{\star \star \star \star}$.

${ }^{2}$ Excluding the 6 cases of posterior myocardial infarction with previous anterior myocardial infarction (3 with and 3 without atrioventricular block): this decreases the number of cases with normal atrioventricular conduction to $5 \mathrm{I}^{\star}$, the number of cases with atrioventricular conduction disorders to $37^{\star \star}$, the number of cases with severe atrioventricular conduction disorders to $28^{\star \star \star}$, and the number of cases with 'unstable' atrioventricular conduction disorders to $18 \star \star \star \star$.

TABLE 4 Predictive value of leads $V_{4} R$ and $V_{3} R$ in conduction disorders in acute posterior myocardial infarction

\begin{tabular}{|c|c|c|c|c|c|c|}
\hline & \multicolumn{6}{|c|}{ Morphology of $V_{4} R$ and $V_{3} R$} \\
\hline & \multicolumn{2}{|c|}{$S T$ elevation } & \multicolumn{2}{|l|}{$Q S^{\star}$} & \multicolumn{2}{|c|}{$S T$ elevation $+Q S^{\star}$} \\
\hline & $\begin{array}{l}\text { Present } \\
\text { (44 cases) }\end{array}$ & $\begin{array}{l}\text { Absent } \\
\text { (50 cases) }\end{array}$ & $\begin{array}{l}\text { Present } \\
\text { (23 cases) }\end{array}$ & $\begin{array}{l}\text { Absent } \\
(58 \text { cases })\end{array}$ & $\begin{array}{l}\text { Present } \\
\text { (I5 cases) }\end{array}$ & $\begin{array}{l}\text { Absent } \\
\text { (66 cases) }\end{array}$ \\
\hline $\begin{array}{l}\text { All disorders of atrio- } \\
\text { ventricular conduction } \\
\text { ( } 40 \text { cases) }\end{array}$ & $\begin{array}{l}66 \% \\
(29)\end{array}$ & $\begin{array}{l}22 \% \\
\text { (II) }\end{array}$ & $\begin{array}{l}70 \% \\
(16)\end{array}$ & $\begin{array}{l}31 \% \\
\text { (18) }\end{array}$ & $\begin{array}{l}80 \% \\
\text { (12) }\end{array}$ & $\begin{array}{l}33 \% \\
(22)\end{array}$ \\
\hline $\begin{array}{l}\text { Severe atrioventricular } \\
\text { conduction disorders } \\
\text { ( } 29 \text { cases) } \\
\text { Unstable atrioventricular } \\
\text { block ( } 20 \text { cases) }\end{array}$ & $\begin{array}{l}50 \% \\
(22) \\
36 \% \\
(16)\end{array}$ & $\begin{array}{l}\text { I } 4 \% \\
(7) \\
8 \% \\
(4)\end{array}$ & $\begin{array}{l}56 \% \\
(13) \\
39 \% \\
(9)\end{array}$ & $\begin{array}{l}19 \% \\
(\mathrm{II}) \\
\mathrm{I4} \% \\
(8)\end{array}$ & $\begin{array}{l}67 \% \\
(10) \\
60 \% \\
(9)\end{array}$ & $\begin{array}{l}21 \% \\
(14) \\
12 \% \\
(8)\end{array}$ \\
\hline
\end{tabular}

Number of cases is in parentheses.

* Excluding the 13 cases of recurrent myocardial infarction ( 6 with atrioventricular conduction disorders).

significant difference between the subgroup with unstable conduction disorders and the subgroup with severe conduction disorders.

The predictive value of the signs in leads $V 4 R$ and $V_{3} R$ in the 94 cases of acute posterior myocardial infarction is shown in Table 4, which indicates the number of cases in which these signs in leads $V_{4} R$ and $V_{3} R$ were present or absent in each of the three groups: no disorders of atrioventricular conduction, disorders of atrioventricular conduction irrespective of severity, are severe and 'unstable' conduction disorders, as defined in the preceding section.
When a raised ST segment was present in leads $V_{4} R$ and/or $V_{3} R$, the myocardial infarction was complicated by atrioventricular block in 66 per cent of cases; the disorder of conduction was severe in half of the cases $(50 \%)$ and unstable in one-third $(36 \%)$. When this sign was absent, atrioventricular conduction disorders were found in only 22 per cent of cases, and were severe in only 14 per cent, and unstable in only 8 per cent. Similar percentages were found for QS pattern (Table 4). The association of both signs (raised ST segment and QS pattern) in leads $V_{4} R$ and/or $V_{3} R$ was rarer ( 15 cases). When present, the myocardial infarction 

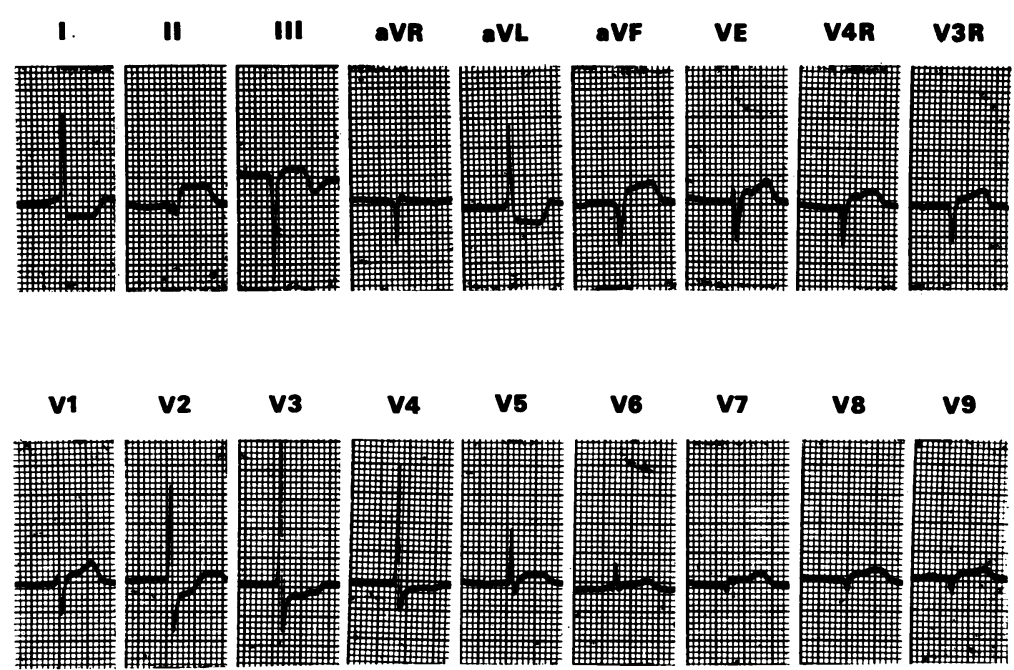

।

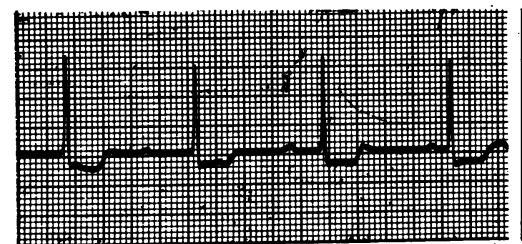

V1

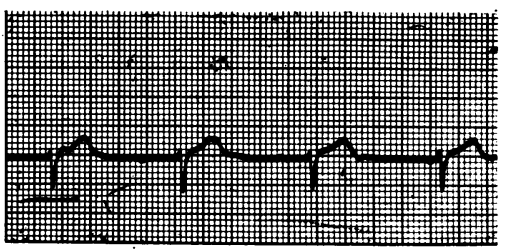

FIG. 2 Acute posterodiaphragmatic myocardial infarction in a 58-year-old man. Complete atrioventricular block. Introduction of an intracavitary stimulating catheter. Repeated episodes of ventricular tachycardia. Electromechanical dissociation and death on day 7. The tracing on day 2 shows $Q S$ pattern in lead $V 4 R$ and elevation of $S T$ segment $(I .5 \mathrm{~mm})$ in leads $V_{4} R$ and $V_{3} R$. Complete atrioventricular block with normal duration of $Q R S$ complex $(0.06 \mathrm{sec})$ and ventricular rate of 65 beats/min.

was complicated by atrioventricular block in 80 per cent of cases; the disorder of conduction was severe in two-thirds of cases $(67 \%)$ and unstable in almost two-thirds of cases $(60 \%)$. The percentage differences between the groups with and without disorders of atrioventricular conduction are statistically highly significant $(P<0 \cdot 00 \mathrm{r})$. On the other hand, there is no significant difference between the subgroup with severe conduction disorders and the subgroup with unstable conduction disorders.

\section{Comment}

The percentage $(\mathbf{4 2} .5 \%)$ of cases of atrioventricular block in our series of 94 patients with posterior myocardial infarction is clearly greater than the usual incidence of atrioventricular block in posterior myocardial infarction, and is explained by the particular selection of the patients directed to an intensive coronary care unit. The type of conduction disorder in posterior myocardial infarction depends on the location of anatomical lesions (Hecht and Kossmann, 1973; Roubelakis, Grosgogeat, and Lenègre, I966; Lev, Kinare, and Pick, 1970). It is possible schematically to contrast the heart blocks observed in anterior myocardial infarction with those seen in posterior myocardial infarction (Blondeau et al., 1967). In the latter, the conduction pathways are protected by the fibrous bridge of the atrioventricular ring (Blondeau et al., 1967). Their involvement is always partial, which explains the transient character of conduction disorders (Blondeau, Rizzon and Lenègre, I96I ; James, I969). But all authors lay stress on the fact that the commonly 


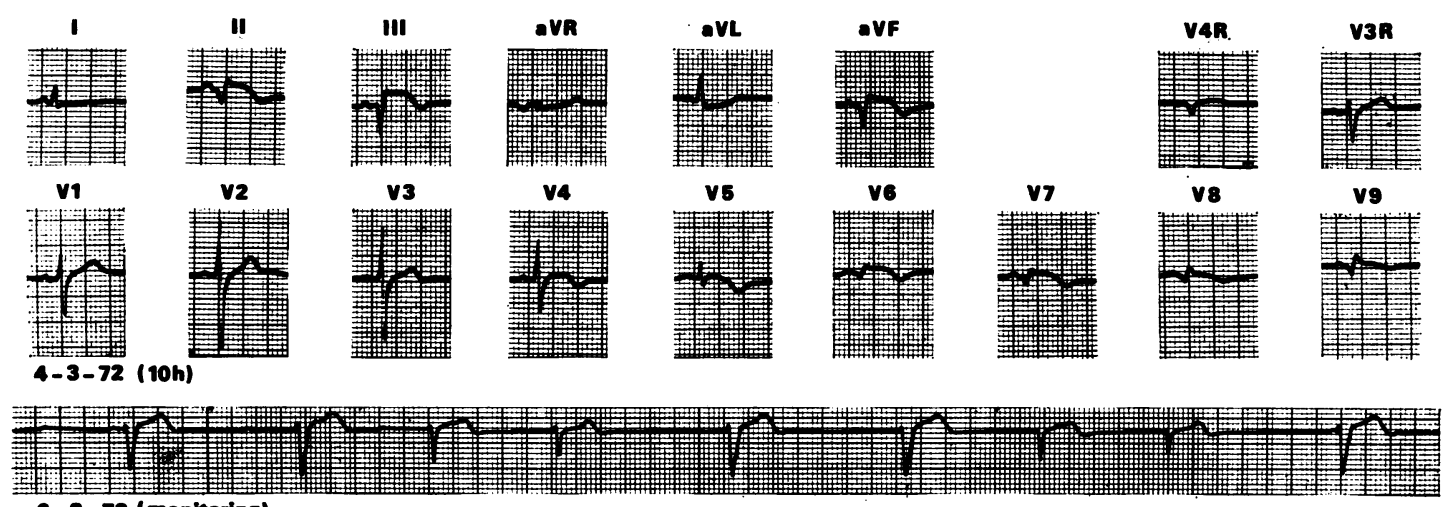

6-3-72 (monitoring)

FIG. 3 Acute posterolateral and posterobasal myocardial infarction in a 73-year-old woman. Death from cardiac rupture on day 6. The tracing recorded at the Ioth hour shows the presence of $Q S$ pattern and $S T$ segment elevation $(\mathrm{I} \mathrm{mm}$ ) in lead $V 4 R$. On day 3, the monitoring tracing shows an advanced atrioventricular block with average heart rate slowing to 50/min. The $3 r d$, 4 th, 7 th, and 8th QRS complexes are probably supraventricular in origin, with much lengthened $P R$ intervals; the other $Q R S$ complexes are ventricular escape beats.

called 'posterodiaphragmatic' infarction ${ }^{1}$ is actually posteroseptal: necrosis extends very high in the posteroseptal dihedral angle in the vicinity of the atrioventricular node and main bundle (Blondeau et al., I96I), which are likely to be involved (Puech and Grolleau, 1972; Rosen et al., 1970). The involvement of the atrioventricular conduction pathway, observed histologically in 3 cases of the present series, though usually partial in posterior myocardial infarction, may be important. As a result, some cases of posterior myocardial infarction require temporary pacing.

The results observed show a close relation between the electrocardiographic changes found in leads $V_{3} R$ and/or $V_{4} R$ and the development of atrioventricular conduction disorders. The cases of posterior myocardial infarction with direct signs of injury in leads $V_{3} R$ and/or $V_{4} R$ were complicated three times as often by atrioventricular block as when these signs were absent. The introduction of a stimulating catheter was required in a third of the cases, in which these signs were present. The association of raised ST segment and QS pattern in leads $V_{3} R$ and/or $V_{4} R$ was found in the most severe disorders of atrioventricular conduction.

The electrocardiographic changes are not caused by a necrosis of the right ventricle. The results of anatomical (Roubelakis et al., I966) and electrocardiographic investigations (Lenègre, Carouso, and Chevalier, 1954) enable us to state that right ventricular infarction is rare and produces no

${ }^{1}$ Signs of necrosis in leads II, III, aVF. characteristic electrocardiographic signs. In the 8 cases of the present series in which necropsy was performed, an extension of necrosis to the posterior wall of the right ventricle was found in 2 cases, but signs found in leads $V_{3} R$ and/or $V_{4} R$ may be the expression of a more important septal involvement than that observed in posterior myocardial infarction not complicated by atrioventricular block.

We did not undertake any systematic study of intracardiac His bundle potentials in patients with or without changes in leads $V_{4} R$ and $V_{3} R$. Such a study would make it possible to identify the location of conduction disorders, usually proximal to the bundle of His (Touboul et al., I972), but this examination, though readily undertaken in an intensive care unit (Scherlag et al., 1969), is usually carried out only when the atrioventricular block is already established, and cannot be used to predict the development of conduction disorders in acute myocardial infarction.

\section{Conclusion}

The recording of leads $V_{4} R$ and $V_{3} R$ is an easy procedure that enables one to predict which patients with posterior myocardial infarction are the most likely to develop disorders of atrioventricular conduction. Special attention should therefore be given to those cases of acute posterior myocardial necrosis with signs of injury in leads $V_{4} R$ and/or $V_{3} R$. The presence of these signs seems to indicate septal involvement, intermediate between pure posterior involvement and extensive septal necrosis. 


\section{References}

Blondeau, M., Maurice, P., Reverdy, V., and Lenègre, J. (1967). Troubles du rythme et de la conduction auriculoventriculaire dans l'infarctus du myocarde récent: considérations anatomiques. Archives des Maladies du Coeur et des Vaisseaux, 60, 1733.

Blondeau, M., Rizzon, P., and Lenègre, J. (196I). Les troubles de la conduction auriculo-ventriculaire dans l'infarctus myocardique récent. I. Etude clinique. II. Etude anatomique. Archives des Maladies du Coeur et des Vaisseaux, 54, 1092 and 1104.

Chaignon, M. (1972). Contribution à l'étude des troubles de conduction auriculo-ventriculaire dans les infarctus postérieurs. Intérêt des dérivations $V_{4} R$ et $V_{3} R$. Thèse, Paris.

Christiansen, I., Haghfelt, T., and Amtorp, O. (1973). Complete heart block in acute myocardial infarction: drug therapy. American Heart fournal, 85, I62.

Delahaye, J. P., Touboul, P., Clement, Ch., Ducluzeau, R. Perrot, E., and Boissel, J. P. (197I). L'électrostimulation endocavitaire dans les troubles de conduction de l'infarctus du myocarde. Archives des Maladies du Coeur et des Vaisseaux, 64, 813.

Friedberg, C. K., Cohen, H., and Donoso, E. (1968). Advanced heart block as a complication of acute myocardial infarction. Role of pacemaker therapy. Progress in Cardiovascular Diseases, 10, 466.

Guerot, Cl., Valere, P. E., Castillo, A., Zelasko, Y., and Tricot, R. (1973). Aspects inhabituels des blocs auriculoventriculaires au cours de l'infarctus du myocarde. Coeur, 4, 44I.

Hackel, D. B., and Estes, E. H. (197I). Pathologic features of atrioventricular and intraventricular conduction disturbances in acute myocardial infarction. Circulation, 43, 977.

Hecht, H. H., and Kossmann, C. E. (1973). Atrioventricular and intraventricular conduction; revised nomenclature and concepts. American fournal of Cardiology, 31, 232.

James, T. N. (1969). Pathogenesis of arrhythmias in acute myocardial infarction. American fournal of Cardiology, 24, 791.

Kaltman, A. J. (197I). Indication for temporary pacemaker insertion in acute myocardial infarction. American Heart fournal, 81, 837.
Lassers, B. W., and Julian, D. G. (1968). Artificial pacing in management of complete heart block complicating acute myocardial infarction. British Medical fournal, 2, 142.

Lenègre, J., Carouso, G., and Chevalier, H. (1954). Electrocardiographie Clinique. Masson et Cie, Paris.

Lev, M., Kinare, S. G., and Pick, A. (1970). The pathogenesis of atrioventricular block in coronary disease. Circulation, 42, 409

Norris, R. M. (1969). Heart block in posterior and anterior myocardial infarction. British Heart fournal, 31, 352.

Puech, P., and Grolleau, R. (1972). L'activité du Faisceau de His Normal et Pathologique, Vol. I, p. 142. Ed. Sandoz, Paris.

Rosen, K. M., Loeb, H. S., Chuquimia, R., Sinno, M. Z. Rahimtoola, S. H., and Gunnar, R. M. (1970). Site of heart block in acute myocardial infarction. Circulation, 42, 925.

Roubelakis, G., Grosgogeat, Y., and Lenègre, J. (I966). Les infarctus bi-ventriculaires: étude anatomo-électrique. Archives des Maladies du Coeur et des Vaisseaux, 59, 39I.

Scherlag, B. J., Lau, S. H., Helfant, R. H., Berkowitz, W. D., Stein, E., and Damato, A. N. (1969). Catheter technique for recording His bundle activity in man. Circulation, 39, 13.

Schluger, J., Iraj, I., and Edson, J. N. (1970). Cardiac pacing in acute myocardial infarction complicated by complete heart block. American Heart fournal, 80, I 16.

Slama, R., Motte, G., and Coumel, P. (1971). Les Blocs Auriculo-Ventriculaires, Vol. I. Editions J. B. Baillière et fils, Paris.

Touboul, P., Clement, C., Porte, J., Magrina, J., and Delahaye, J. P. (1972). Etude électrophysiologique des troubles de conduction auriculoventriculaire dans l'infarctus myocardique récent. Archives des Maladies du Coeur et des Vaisseaux, 65, 1287.

Watson, C. C., and Goldberg, M. J. (I97I). Evaluation of pacing for heart block in myocardial infarction. British Heart fournal, 33, 120.

Requests for reprints to Dr. A. Barrillon, Service de Cardiologie, Hôpital Boucicaut, 78 rue de la Convention, 75730 Paris cedex 15, France. 